\title{
The debating tradition in Britain and the new political economy: William Thompson and John Stuart Mill at the London Co-operative Society in 1825
}

A tradição de debates na Grã-Bretanha e a nova economia política: William Thompson e John Stuart Mill na Sociedade Cooperativa de Londres em 1825

\author{
Carlos Leonardo Kulnig Cinelli (1) \\ Rogério Arthmar (2) \\ (1) Universidade de Brasília \\ (2) Universidade Federal do Espírito Santo
}

\begin{abstract}
This paper reviews the debate between William Thompson and John Stuart Mill that happened at the London Co-operative Society in 1825 over the advantages of cooperation as against free competition. The general context of the controversy is provided by some historical background on British debating tradition within the working people. Next, the philosophical doctrines of Jeremy Bentham and Robert Owen are outlined as the main forces of social change in the 1820 s, both of which would collide during the faceoff at the Co-operative Society. Following that, we examine William Thompson's ideas on income distribution and the moral evils of competition. Lastly, we present John Mill's approach to these same issues, showing that his basic conception of individual liberty did not change throughout his life, despite his late agreement with the economic benefits of cooperation. The final remarks stress the originality of the theoretical elements put forth in the debate.
\end{abstract}

\section{Keywords}

free speech, cooperation, competition, social reform, liberty.

JEL Codes B12, B14, B31.

\section{Resumo}

$O$ artigo analisa o debate entre William Thompson e John Stuart Mill ocorrido na Sociedade Cooperativa de Londres em 1825 a respeito das vantagens do cooperativismo face ao sistema competitivo. O contexto geral da controvérsia é apresentado por meio de uma revisão histórica da tradição de debates entre os trabalhadores britânicos. Após, as doutrinas filosóficas de Jeremy Bentham e Robert Owen são delineadas por se tratarem das duas principais forças de mudança social no país nos anos de 1820, as quais viriam a colidir durante o enfretamento na Sociedade Cooperativa. Na sequencia, examinam-se as ideias de William Thompson sobre a distribuição de renda e os males morais derivados da concorrência. Finalmente, revisa-se a abordagem de John Stuart Mill para tais temas, mostrando-se que a sua concepção básica da liberdade individual não se modificou ao longo de sua vida, a despeito de sua posterior concordância acerca dos benefícios do cooperativismo. As conclusões realçam a originalidade dos elementos teóricos utilizados no debate.

\section{Palavras-chave}

livre-expressão, cooperativismo, concorrência, reforma social, liberdade.

Códigos JEL B12, B14, B31. 


\section{Introduction}

Sometime around the middle of the eighteenth century, Britain witnessed the blossoming of workers' associations conceived to promote the free exchange of ideas about political, religious, and other daily life subjects. That represented a large step forward in the makeup of ordered spaces of sociability and the advancement of knowledge for the common people, a privilege that had until then been allowed exclusively to the Parliament, universities, and some private aristocratic groups. As time went on, these forums became also a hotbed for new kinds of organizations, as corresponding networks and even scientific societies. Located in large assembly halls, but mostly in alehouses and taverns, where people were used to getting together regularly, many of these places provided the ideal milieu for radical activists to preach in front of large audiences their message of political change. As the French Revolution grew more volatile and Britain declared war on France, a wide variety of coercive measures were put in place to quell political debates and free speech among the British population.

After the war, the repressive policy stayed in effect until 1822, when a more open attitude by authorities toward the radical press and public meetings permitted the rebirth of debating societies, which had almost vanished entirely during the previous period. That was the time when the cooperative movement took off in the country and the reformist message started to gain traction, culminating the next decade in the Chartist Movement. The urge for more democratic arrangements and social change in this new situation could not fail to bring under scrutiny the teachings of political economy as opposed to the emerging drive to cooperation. This direct confrontation would eventually come about in 1825 at the London Co-operative Society, when speakers for both camps met regularly for a period of three months to dispute the merits of their respective doctrines.

At the occasion, the British classical school was in process of consolidation around some basic canons. The economists associated with that line of thought, such as Adam Smith, David Ricardo, Thomas Malthus, and John R. McCulloch, deemed it essential to the progress of wealth the suppression of all restrictive laws affecting the productive domain in order to pave the way for the action of self-interest within a competitive environment. Moreover, human desire for conveniences being unlimited, no general overproduction could ever take place, except in some very particu- 
lar instances, due to errors of forecast by some producers, although here Malthus found a lot to disagree with. Jeremy Bentham, a central figure of the period under consideration, espoused many of these economic ideas, but kept pressing upon the imperative of large-scale constitutional changes designed to promote more positively the happiness of society ( $\mathrm{O}$ 'Brien 2004: 1-18; Schumpeter 1963: 379-402; Checkland 1949; Stephen 1912: 235-280).

For many dissatisfied thinkers, however, such a confident picture of the prevailing political and economic conditions in Britain sounded excessively conformist. Although in incipient form, the early 1820s marked the emergence of an alternative literature intent on challenging the basic principles of political economy, including its scope, analytical tools, and objectives. Robert Owen, George Mudie, and William Thompson, among others, were key protagonists of this movement. Before long, the revenue of capitalists and landowners, as previous agrarian reformers had insisted upon, began to be denounced as being rooted in the exploitation of the working classes, while the industrial order was appointed now as the chief cause of people's poverty amid the material abundance of the time. Contemporary popular writers agreed that the eradication of such iniquity would require a profound restructuring of society, particularly through the association of workers in self-managed communities $(\mathrm{N}$. Thompson 2002: 35-110, 158-190; Claeys 1987a: 34-156; Schumpeter 1963: 454-462; Gray 1946: 262-296).

These two antagonistic conceptions of the methods and ends of political economy, as mentioned, would clash head-on at the London Cooperative Society, in a rather singular event in British intellectual history. To cover that episode, the second section recaps the historical evolution of debating societies in Britain by the end of the eighteenth century. The third section goes over Bentham's and Owen's doctrines of social change, which inspired the two main speakers of the 1825 showdown. The fourth section inspects W. Thompson's propositions on equality and cooperation as put forward in his most famous book published the preceding year. The fifth section is dedicated to analysing John Mill's ideas on competition and liberty as expressed in his extant notes for his two speeches at the Society. His early views on these matters are also compared with his changed assessment of cooperation and socialism later in life. In the end, some considerations are presented as to the relationship between the teachings 
of classical economists and the arguments of the then emerging popular political economy.

\section{The debating tradition in Britain}

By the mid-eighteenth century, a movement in Britain started to take shape through the formation of debating societies in taverns and alehouses, where the common people, at a modest price, could contend freely over themes spanning politics, religion, or legal issues. Most of the participants were small shopkeepers, craftsmen, or clerks, who could afford the entrance fee, but who happened to be entirely excluded from the nation's political life. The Robin Hood Society was the first and most famous debating organization created in London around 1740, whose model was soon reproduced all over Britain and even in the American colonies. Some of these societies became touristic attractions and were visited occasionally by a known politician or literati, although their fame arose mostly from the gathering of disenfranchised men of the lower ranks to speak up their minds. That circumstance eventually drew the attention of the traditional press, which was worried about the subversive danger of heated debates among the "uneducated mob". As the number of this kind of establishment grew larger, the organizers started to rent more spacious halls and advertise their weekly activities in the newspapers, generating thus a regular attendance and a moderate profit, although many societies set aside a fraction of their revenue for philanthropy. Mary Thale has described the exemplary role of the Robin Hood Society as follows:

\footnotetext{
The speakers as a whole made the Robin Hood the one forum where large numbers of men of the middling and lower ranks could assemble to question the doctrines of the Church and the decisions of Parliament. Although such issues could be discussed in public houses and at work, the Robin Hood provided a disciplined framework for such talk as well as the possibility of a greater variety of views (Thale 1997: 39).
}

In 1780, there were more than thirty debating societies in London alone, many of which had sprung up either from convivial clubs of commercial citizens, mooting courts of law students, or even from spouting clubs where pretending actors met to practice their skills. Around three hundred advertisements of debates filled out the London newspapers that sole year. Women were usually allowed in the more sophisticated premises, where 
strict rules prevailed about the obligation of good manners and cordiality during the proceedings. The frequent subjects of discussion there ranged from the relationship between the sexes to education, notorious trials and, of course, current political issues (Andrew 1996). Most of these societies, however, convened at taverns or alehouses, essentially congregating the ordinary man and partaking of a more radical nature. There, the official religion, the rampant corruption in the political sphere and even the prevailing social structure were freely criticized, to the dismay of contemporary periodical writers. ${ }^{1}$ The ideological influences in this environment, most often came from William Cobbett's inflammatory writings preaching parliamentary reform, as well as from the agrarian reformers Thomas Paine and Thomas Spence who, inspired by John Locke's doctrine of natural law and original contract, had been denouncing the injustice of land property while claiming the need for more democracy (N. Thompson 2002: 35-53; Cole 1953: 31-35; Gray 1946: 257-262). ${ }^{2}$

All this effervescence came to a head with authorities during the French Revolution. For the diffuse subjects of discussion in the early times progressively gave way to the dominance of hot political issues involving parliamentary reform, republicanism, and land distribution, while some debating organizations had been also working as a nursery for large corresponding societies. Fearing that such structure could end up replicating the Jacobin Parisian clubs, King George III, urged by Prime Minister William Pitt, issued The Royal Proclamation Against Seditious Writings and Publications on 21 May 1792 to curb possible seeds of domestic rebellion. Besides that, the royal repression of debating societies at the time comprised not only the extensive infiltration of spies and provocateurs into

1 For instance, The Crown and Anchor Tavern, located in a four-storey building at the Strand, London's central business area, was well known from 1790 to the middle of the nineteenth century as a meeting point for reform campaigners and radical groups. Its assembly room could accommodate up to two thousand people. Their customers called it "The Temple of Liberty", while the press often discredited it as the headquarters of treachery and revolution or yet, in more colourful wording, "The Gate of Pandemonium" (Parolin 2010: 105-146). 2 In 1812, Thomas Spence constituted an organization of his followers, who became known as Spenceans, comprising four branches of ten seasoned agitators each to widen his personal influence over the working people in London. Their message involved the confiscation of lands and the repudiation of the national debt. Among those men were Thomas Evans, successor of Spencer as leader of the organization; John Hooper, a physician; Thomas Preston, a leather worker, and Arthur Thistlewood, later implicated in the Cato Street Conspiracy to assassinate the British cabinet, for which he paid with his life in 1820. Some of the Spenceans were arrested for treason but acquitted in 1816. Their organization was outlawed in 1820 (Beer 1923: 140-142). 
those bodies but also the intimidation of tavern owners by magistrates, who threatened to cancel their licences if political meetings took place in their properties. Furthermore, habeas corpus was officially suspended from 16 May 1794 to July 1795 and, after that, from April 1798 to March 1801.

In that first interval, about sixty reformers from all over the kingdom were arrested for high treason, twenty of them from London, including the shoemaker Thomas Hardy and the merchant and radical debater John Thelwall, founders of the London Corresponding Society. ${ }^{3}$ An alleged attempt at the life of the King motivated the passing of the Seditious Meetings Act, in December 1795, restricting the size of political meetings to fifty people and requiring previous authorization by a magistrate. The predictable outcome of all these repressive measures was the closing or disbanding of most debating and corresponding societies for almost a decade at the end of the eighteenth century. However, some ingenious radical figures reacted to such an oppressive state by disguising their activities through the cover of religious dissenting ministries, which authorities had far greater difficulty in obliterating (Thale 1989; McCalman 1987).

Britain's military success at the end of the Napoleonic Wars in 1815 did not alleviate any of its economic problems. The national debt had grown massively, war inflation had been substantial, and demobilization brought about all around economic distress and unemployment (Hyndman 1902: 18-23). The landed aristocracy quickly passed the Corn Laws in 1815 to avoid cheap food imports. Discontentment and revolt took over the nation, but were still treated by repressive countermeasures, although most indictments for sedition or high treason at peace conditions ended up in acquittals by popular juries. With the suspension of habeas corpus expired, unions, associations, and reading clubs of common people began to spring up once again. The parliamentary reform agitation gathered momentum. Strikes and large public rallies swept the northern region of the country, until the Peterloo massacre of 16 August 1819 in Manchester, when eleven persons were killed and hundreds more hurt after the yeomanry charged against an unarmed crowd of around sixty thousand people. The govern-

3 The London Corresponding Society was founded in 1792 as an offshoot of the Society for Constitutional Information, a reformist club created in 1780 by men of prestige. The more popular LCS had as its main purpose to spread the principles of universal suffrage and annual parliaments. Such goals were to be achieved by the dissemination of knowledge to ordinary people through reformist literature on politics and morals. At its peak, in 1795, the LCS had around three thousand paying members (Weinstein 2002). 
ment, afraid of new disturbances, arrested several radical figures and introduced the Six Acts legislation, approved by Parliament on 30 December 1819 , forbidding outdoor meetings of any sort, save those behind closed doors and not exceeding fifty people, and stipulating yet tougher punishments for seditious writings, along with the taxing of the radical press, among other actions of similar nature (Halévy 1949: 54-79; Trevelyan 1930: 180-194).

The death of Prime Minister Lord Castlereagh in 1822 and the ascension of the young Robert Peel to the Home Secretary brought about silent and fundamental changes to the government's policy toward free speech and public meetings. No more undercover spies and saboteurs were to be sneaked into the workingmen ranks, and prosecutions of the press came to an end. A fresh wind began to blow. By the initiative of the master tailor and Benthamite agitator Francis Place, along with Joseph Hume, an independent commoner, the Combination Acts of 1799 and 1800, which had been enacted in fear of the potential revolutionary character of workers' associations, were quietly suppressed by the Parliament on 5 July 1824, albeit a subsequent Act of 1825 would limit some excesses of trade unions (Shawl 1954: 53-92). Parallel to that, and despite the coercive legislation, a rapid growth of reading rooms happened in coffee-houses and bookstores, where a poor man could get at once leisure and access to newspapers and controversial pamphlets made more expensive by the new duties imposed upon the alternative press. As Iain McCalman has remarked, the radical movement in Britain always understood as crucial the instruction of the working people, and to that end, regular spaces of debate and exchange of information remained essential:

In the midst of all the drilling and plotting of 1798 John Baxter, President of the Sons of Liberty, was busy organizing 'questions for the Society to debate and enlighten their minds', whilst Blythe's section of United English debaters voted in January 1799 that 'a school to enlighten their minds' preceded all other goals in importance, including the attainment of a representative assembly. Spenceans similarly advocated educational goals throughout the period of their formal existence from 1801 to 1820 (McCalman 1987: 320).

As the official repressive structure began to wind down from 1824 onwards, when the Seditious Meetings Prevention Act expired, the overall effects of the long Tory policy of suffocating the rights to speak at liberty were twofold. First, it brought to daylight the outdated and cumbrous nature of British laws, particularly of its penal code, prescribing medieval and 
ruthless punishments for acts of free speech. Second, it rendered the common man outright suspicious of any reformist rhetoric bearing an authoritarian scent. The British working-class ideology that began to mature from the 1820s well into the nineteenth century put exceptional value on unrestricted press, free speech, public meetings, and personal liberty. Edward P. Thompson, in his well-known history of the working class in England, offered to this strong disposition to intellectual inquiry and mutuality by the British worker in those years a vivid explanation:

\footnotetext{
The autodidact had often an uneven, laboured understanding but it was his own. Since he had been forced to find his intellectual way, he took little on trust: his mind did not move within the established rules of a formal education. Many of his ideas challenged authority, and authority had tried to suppress them. He was willing, therefore, to give a hearing to any new, anti-authoritarian ideas... By mutuality we mean the tradition of mutual study, disputation, and improvement. We have seen something of this in the days of the L.C.S. The custom of reading aloud the Radical periodicals, for the benefit of the illiterate, also entailed as a necessary consequence that each reading devolved into an ad hoc group discussion (E.P. Thompson 1963: 743; italics in the original).
}

The political climate in the 1820 s, therefore, was well suited to bring up and carry forward the message of legal and social reform in Britain. And two names would stand out in this process, having a decisive bearing on the history of the period and, therefore, on the remaining sections of this paper, namely, Jeremy Bentham and Robert Owen.

\section{Bentham and Owen on social reform and the Lon- don Co-operative Society}

Jeremy Bentham, despite his facility for conceiving original solutions in the form of legal prescriptions to wide-reaching social issues, nurtured no sympathy for any species of socialistic doctrine. ${ }^{4}$ Poverty, as argued in his Principles of the Civil Code (1802), was the primitive condition of man, and the fast growth of population in modern times attested to the superiority of

4 Jacob Viner, when assessing the legacy of Bentham and his followers, noted: "They were 'Radical Reformers', and they worked hard at their reforms: by working out detailed blueprints for them; by propaganda, agitation, intrigue, conspiracy; and, if truth be told, by encouragement to revolutionary movements up to -but not beyond- the point where resort to physical force would be the next step" (Viner 1949: 361-362; for a thorough analysis of the evolution of Bentham's political radicalism, see, for instance, Crimmins 1994 and Halévy 1969: Part II, chaps. I and III). 
the regime of property in creating enough wealth to sustain the poor. Any attempt at subverting the right of property would suffocate self-interest and promote the flight of entrepreneurs, converting the kingdoms of prosperity into deserts of scarcity (Bentham 1938 [1802]: 308-312, 341-342).

In his Leading Principles of a Constitutional Code (1823), Bentham also declared, based on the principle that people always act to reach maximum pleasure and to avoid pain, that the objective of any social project should be to achieve the greatest happiness for the largest number. ${ }^{5}$ This noble desideratum would involve the attainment of four complementary goals, that is: subsistence, abundance, security, and equality. The first two depended on the production of wealth, which was required both to guarantee the provision of things whose absence might cause physical pain and, beyond that, to afford means of felicity. The third goal, security, considered paramount by Bentham, might be either for good, assuring the right of property on the articles of abundance, or for evil, against calamities or evil-doers. As for equality, the last goal, it should be promoted as long as it does not conflict with the other previous goals. The harms coming from inequality, explained Bentham, could be either civil, meaning the loss of happiness due to the uneven distribution of wealth, or yet constitutional, involving the abuse of power by rich individuals.

Hence, throughout the whole population of a state, the less the inequality is between individual and individual, in respect of the share possessed by them in the aggregate mass or stock, of the instruments of felicity, -the greater is the aggregate mass of felicity itself: provided always, that by nothing that is done towards the removal of the inequality, any shock be given to security-security, namely, in respect of the several subjects of possession above mentioned (Bentham 1843 [1823]: 273).

The second prominent social reformer of post-war Britain, the Welsh industrialist and philanthropist Robert Owen, believed firmly that the character of every man was moulded by his living conditions. Owen's conception of a new society received its most articulate presentation in his Report to the Commons' Committee on the Poor Laws (1817). The document attributed the distressful situation of the economy after the war to the progressive mechanization of the country, a process which had been

5 In his Introduction to the Principles of Morals and Legislation (1789), Bentham expressed this axiom in the following terms: "Nature has placed mankind under the governance of two sovereign masters, pain and pleasure. It is for them alone to point out what we ought to do, as well as to determine what we shall do" (Bentham 1938 [1789]: 14). 
motivated by the pressure of competition and which had multiplied the power of creating wealth while making labour redundant, consequently depressing wages and impoverishing millions of families. ${ }^{6}$ The effective relief of unemployment, exhorted Owen, instead of the useless expenditures on the Poor Laws, required indeed the education of children and the safeguarding of men from their daily temptations. To attend both objectives, he proposed the construction of a series of buildings, in the shape of parallelograms, that were capable of accommodating about twelve hundred people each, surrounded by at least a thousand acres of arable land. These communities would contain a lecture room, a public kitchen and comfortable apartments, in addition to separate offices for mechanical arts and farming activities, while every resident would be educated on a variety of crafts. Owen estimated the cost of each unit at $£ 96,000$, to be covered by public borrowing or private funding (Morton 1978: 23-37; Kaufmann 1879: 88-109). ${ }^{7}$

Due to the notoriety of his innovative reforms benefiting the workers of his mill in New Lanark, Owen had turned himself into a kind of celebrity in high political circles in Britain and Europe. Moreover, his confidence, like Bentham's, that the reasonability of his message would be enough to convince men in power to implement his social ideas put him in frequent contact with economic writers of a distinct disposition, who did not hide their scepticism toward the feasibility of Owen's proposals. Those amicable encounters were, perhaps, the first skirmishes between opposing views of political economy in Britain during the first decades of the nineteenth century. Quoting Owen's own recollections:

But I must not forget my friends of the political economists-Messrs. Malthus, James Mill, Ricardo, Sir James Macintosh, Colonel Torrens, Francis Place, etc., etc. From these political economists, often in animated discussions, I always differed. But our discussions were maintained to the last with great good feeling and a cordial friendship. They were liberal men for their time; friends to the national

6 According to George D. H. Cole's outline of Owen's philosophy: "He was driven to the view that nothing worthwhile could be done to amend the lot of the people without two great changes -the eradication of false beliefs about the formation of character, and the abandonment of the unregulated competition which impelled each employer towards inhuman conduct on the plea that his competitors were engaging in it, and that he too must face bankruptcy or do the same" (Cole 1953: 88).

7 In 1919, under the leadership of the Duke of Kent, a Committee was set up including the Duke of Sussex, Sir Robert Peel senior, and David Ricardo, with the purpose of raising $£ 100.000$ to finance an Owenite community, with the promise of a five per cent return on subscriptions. After several months, only $£ 8.000$ had been raised and the whole affair was dismissed (Morton 1978: 38-40). 
education of the people, but opposed to national employment for the poor and unemployed (Owen 1920 [1857]: 143).

It was inevitable, therefore, as the debating tradition in Britain got back on its feet again in the 1820s, that among themes of political or social nature, questions about the tenets and prescriptions of political economy would come to the forefront in discussions involving the fate of massive crowds of urban workers in large industrial centres. There are no records about how or when the London Co-operative Society came into existence, or either when it ceased its activities. The endeavour was, surely, part of a broader movement comprising the flourishing of several kinds of workers' associations throughout Britain at the time. ${ }^{8}$

Arthur John Booth, a historian of these events, has provided a brief account of the Society's creation and objectives. According to him, the institution was set up sometime at the end of 1824 by a few individuals who rented a room in Burton Street to promote debates on problems related to the development of cooperation. The organizers announced each meeting and the main subject of discussion with due notice, inviting everyone to participate freely. As the location was not easily accessible, the Society was removed to Chancery Lane, and after that, to Red Lion Square, which allowed a rapidly expanding attendance. Booth lists the institution's main activities and even recalls the confrontation that motivates the present paper:

As yet their exertions were mainly confined to discussions and literary labour; Mr. Owen explained the New System with his accustomed amplitude of detail. Mr. Combe exhibited a model of his projected building at Orbinston. Mr. Hamilton, of Dalzell, gave the Society his countenance and the prestige of his rank. Political economists of the school of Malthus disputed the soundness of the New View, and sought to excite terror by dismal forebodings. Pamphlets were issued to explain the principles of cooperation, and to disseminate a knowledge of its advantages; lectures were delivered and at length a new journal was started (Booth 1869: 132-133). ${ }^{9}$

8 As Beatrice Potter-Webb has reported about that period: "Meetings, petitions, demonstrations, processions, follow each other in quick succession. A successful attempt to establish a national federation of all the trades, the formation of working men's associations and Radical clubs throughout the country, and the definite adoption by these associations of a well-conceived political programme-the People's Charter-clearly proved the presence of grim determination and organizing capacity among working men and their leaders" (Potter 1904: 55). 9 Booth is probably referring to Mr. George Combe (1788-1858), a famous Scottish writer on human psychology. Combe built a natural museum at the time in Scotland and later wrote one of the nineteenth century best-sellers, The Constitution of Man (1828). The other reference is likely to the Irish Lieutenant-General Sir John James Hamilton (1755-1835), ${ }^{\text {st }}$ Baronet, who fought in several battles during the Napoleonic Wars. 
How the debate between the so-called Malthusian economists and the Owenites came about in 1825 is recalled by John Mill in his Autobiography. As per his memory, one of his friends, John Arthur Roebuck, happened to attend some of the meetings of the London Co-operative Society in Chancery Lane, where he once entered the proceedings speaking against Owenism. Informed about the fact, John Mill, Charles Austin, and some other young members of the just-created Utilitarian Society, proposed to the London Co-operative Society's managers a series of verbal confrontations between Bentham's followers and Owen's sympathizers. Both sides agreed to a sequence of encounters dealing, first, with the broad theme of population. After that, the subject was to change to the merits of Owen's system. John Mill mentions also that the overall showdown, although intense, remained friendly throughout for about three months:

We who represented political economy had the same objects in view which they had, and took pains to show it, and the principal champion on their side was a very estimable man with whom I was well acquainted, Mr. William Thompson of Cork, author of a book on the Distribution of Wealth, and of an Appeal in behalf of woman against the passage relating to them in my father's essay on Government. I myself spoke oftener than anyone else on our side, there being no rule against speaking several times in the same debate (Mill, JSM I 1981 [1873]: 127).

This event is historically important for its being the first instance of a public faceoff between the two opposing strands of British political economy at the time and involving two of their most able representatives. It also reveals the original thoughts of the young Mill on the question of cooperation that would later occupy much of his reflections in mature age, as we are going to see in the sections ahead.

\section{William Thompson on economic security and coop- eration}

Born into a wealthy Irish family, William Thompson entered the public scene in 1818 with a contribution on the theme of education, which put him in contact with Bentham. A few years later, in 1822, Thompson went over to England at the invitation of the utilitarian philosopher and stayed at Bentham's mansion for about fifteen months. Impressed by his host's rationalism and reformist disposition during their acquaintanceship, Thompson adopted the utilitarian principle as one of the main building blocks of 
his critical analysis of the capitalistic order. Owen's vision of cooperative communities would also play a large role in the Irishman's writings, which were published from 1824 to 1830, when he acquired his reputation as one of the leading voices of the labour movement in Britain. However, his fragile health took its tool in 1833, when Thompson passed away due to a lung disease (Pankhurst 1991: 1- 17, 129-136; Lowenthal 1911: 15-17).

Thompson's most distinguished work was An Inquiry into the Principles of the Distribution of Wealth Most Conducive to Human Happiness, published in 1824, which made his name revered within British socialistic groups. Since there are no surviving records of his speech at the London Co-operative Society, this book, which had just been released the year before, can be taken as a valuable indication of the topics he most likely addressed during his talk. Thompson's self-professed objective in this work is to set anew the political economy of his time, whose authors treated labour as a mere element of production, like machines or beasts of burden. Wealth, instead, ought to be considered not only from the strict standpoint of material accumulation, but also from its moral and political aspects if it was to effectively transform political economy in an instrument of human happiness. To do so, the analysis of the most convenient distribution of wealth must have priority over the conditions for its production. Throughout history, wrote Thompson, force, fraud, and usurpation had been the chief causes of inequality, bringing along with them a parade of misery, vice, and degradation. But, on the other hand, when only pure force prevails on society, the security of producers to enjoy the product of their efforts is compromised, therefore weakening their motivation to work. Since equality in incomes would be the ultimate goal of a truly rational community, the key concern of the new political economy should be the reconciliation of this objective with the security of producers in order to ensure the perpetual flow of means to happiness.

For Thompson, Britain was under a social organization marked by an increasing concentration of capital in the hands of a few, while the middle classes were being squeezed down, joining thus the growing afflictions of the multitude of the poor. But even if economic or political expediency called for an unequal distribution of wealth, universal morality and public happiness must reign supreme over other considerations. The quest for equality, insisted Thompson, would be even more compelling if it could be proven that a better social system was capable of satisfying not only 
the productive, but also the political and moral aspects involved in the economic life of man. To this more comprehensive end of political economy, the Inquiry specified three regimes of production, namely: first, by compulsory labour; second, by unrestricted competition; and third, by mutual cooperation, each of them being considered superior to its precedent by its capacity to conciliate security with equality (W. Thompson 1824: xivxix). Or yet, as put forward by Thompson himself when contesting the traditional view of distribution as regulated exclusively by market forces:

[T]o me it appears that the natural laws of distribution, if left freely to operate, would, with the present aids of art and science, do much more than produce to a numerous class, intellectual and moral culture, with the comforts and conveniences of life, and therefore happiness: to me it appears, that what I conceive to be the natural laws or the wisest mode, of distribution, would even produce these blessings to the community at large (W. Thompson 1824: xiii; stress in the original).

Thompson's assessment of the modes of production was based on his three natural laws of distribution, which he borrowed from Adam Smith's idea of competition and barter within a primitive society of individual craftsmen. More specifically: (i) every act of labour must be free and voluntary; (ii) everything originated from labour was to be appropriated by its respective producers; (iii) all exchanges should be free and voluntary. Although all men were considered able to enjoy happiness in the same way, there would never be a practical scale to measure individual susceptibilities. That limitation, however, did not prevent Thompson from invoking the principle of diminishing utility as the foundation of his quest for equality. ${ }^{10}$ In other words, despite the impossibility of calculating the amount of happiness in society, it was legitimate to say, according to him, that a unit of wealth given to a few rich persons would increase their utility in a lesser amount than the corresponding reduction in utility of millions of lower income individuals from whom these units of wealth were taken by deceit or force. By adopting such proposition, Thompson was then able to sustain that total happiness would be augmented whenever inequality was reduced (W. Thompson 1824: 71-75).

10 The cornerstone of Bentham's reformist agenda was the principle of utility, which had already been formulated by David Hume and Joseph Priestley, among other previous philosophers (Halévy 1969: 5-34). Bentham used the terms "pleasure" and "pain" in a broad sense, meaning the feelings of the body, heart and mind. His main contribution, though, dwelled on his disposition to turn this straightforward principle into a method of analysis to address a wide range of social problems (Stephen 1912: 235-248). 
The regime of compulsory labour was seen by Thompson as the one still prevailing in contemporary England, having as its main feature the direct exploitation of the working classes, as suggested by Ricardo through his labour theory of value. The central concept of exploitation in the form of unpaid labour seized by the owner of capital is clearly described in several parts of the Inquiry, as in the following one:

The only article the labourer has to offer for the use or the purchase of these preliminaries to production, land, house, clothes, tools, materials, food, is still a portion of his labour. But so great is usually the proportion of his labour demanded, for the use or advance of these preparatory articles, by those who have appropriated them under the name of capitalists, that by far the greater part of the products of his labour are taken out of his disposal, and consumed by those who have no further share in the production than the accumulation and lending of such articles to the real operative producer (W. Thompson, 1824: 164; see also $36,167,175)$.

This unmerciful system of production had its basis on the private appropriation of both the means of production and knowledge, as well as on the inexcusable gains derived from monopolies and bounties. Since the regime of private property and compulsory labour is built on the foundations of exclusion, says Thompson, it violates the principle of security and, therefore, curbs the exertion of the labourers. Moreover, other evils would come along with the forced inequality of riches, such as the useless consumption of luxury articles, the moral vices of the wealthy, and the corruption of the poor. Still, more important for Thompson was the imposition of unjust laws to sustain a social structure marked by the utter absence of sympathy for the poor by the government, an institution historically managed by the well-off people for their own benefit (W. Thompson, 1824, 179-210).

Thompson was quite emphatic when asserting the advantages coming from a future transition to a universal system of exchanges under unrestricted competition. Once monopolies and bounties were extinct, and the labourers had assured the right to their whole produce, the multiplicity of individual exchanges under a state of free competition would promote the full exertion of each producer toward the development of human industry, as Smith had predicted. That inequality arising from such state of things would be the only one acceptable since, otherwise, the producers' security would be violated, directly hurting the power of society to create wealth. Although the mass of means to happiness happened to be greater under the regime of private capital than under a system of forced equality, this advantage could stand no comparison with the potential growth in 
accumulation brought forth by the division of capital in smaller portions among the working people.

The reasons for these bright hopes by Thompson were manifold. First, he held that the waste associated with luxurious consumption and extravagance would disappear. Second, there would be no further losses of that part of the capital stock deployed to attend the demand arising from the caprices of fashion subjected to sudden changes. Third, the diversion of resources to consumption by the capitalists whenever the profit rate experienced a fall would come to an end. Fourth, the supply of loans to finance foreign wars would dry up, saving the community not only the whole amount of the public debt but also the corresponding payments of interest. And, last of all, with the whole result of labour being now kept by its producers, the workers would direct their energies to the fullest to expand their means of gratification.

The yearly produce, and consumption of the products of labor, to increase enjoy-
ment, being the real object of rational effort, in comparison to the extent of which
productive power, the extent of accumulation is as nothing, and accumulation
being considered merely as a means to this great end, the universal desire of en-
joyment and of production as the only path to lead to enjoyment, would ensure to
everyone the possession of the capital required for such purposes. Every year, as
human labor became more productive by machinery or otherwise, the rewards of
labor would be increased: houses, machinery, dress, food, would be improved, not
for a few accumulators or capitalists, but for all. Capital would be increased in
a tenfold ratio, though in masses almost equal and universally diffused, because
everyone would be interested in its accumulation (W. Thompson 1824: 170).

Considering then the auspicious material gains to be reaped from the system of individual security, why should anyone worry about reforming society? For Thompson, that is when the moral aspects of the economic order come to the forefront. A closer look at the operation of free competition would reveal a series of evils associated with the capitalistic regime of production and most often kept hidden in the reflections of political economists. The supremacy of selfishness, in Thompson's mind, meant that everyone would seek his self-interest irrespective of the well-being of others, corroding any attempt at benevolence. In addition, the structure of families under the system of private property excluded women from all social and productive life, confining one half of the human race to sterile domestic tasks. Also, the uncertainty about market conditions when each one acts as a small capitalist could lead to heavy personal losses every time the actual demand for some particular article was mistakenly predicted. Another moral evil of competition, according to Thompson, lay in its fail- 
ure to provide against the misfortunes of illness and old age, hampering the physical ability of the labourer to stay economically functional. Lastly, as long as individuals do their utmost to conceal productive innovations from other producers, the advancement of knowledge, an essential ingredient to human progress, would be held back by competition (W. Thompson 1824: 367-380). As to this last aspect, one reads in the Inquiry:

\begin{abstract}
Still while individual competition lasts, everyone must endeavour to make available for the increase of his individual hoard, though all were capitalist laborers, whatever powers of mind or body he might possess. To endeavour to render these powers common to all, would be to divest himself with his own hand of his advantages for the acquisition of happiness. Concealment, therefore, of what is new or excellent from competitors, must accompany individual competition, though shielded by equal security, because the strongest personal interest is by it opposed to the principle of benevolence (W. Thompson 1824: 379).
\end{abstract}

Thus, in Thompson's opinion, the greatest aim of a sound political economy, or yet the compatibility between the security of labour and the equality of incomes, could be achieved only in a truly cooperative society on the basis proposed by Owen. That was so because the members of this new system would voluntarily embrace the principle of equality, at the same time dispensing with any use of force. Everyone, proposes Thompson, should then be trained in several useful activities in order to alternate between employments within the community. Besides the economic benefits reaped from free competition, the system of cooperation would also save the waste of life, health, and happiness arising from the poverty created by the regime of individual security. Thompson is indeed quite confident about the virtuous properties of this new social structure. "Within the community, there would be no materials for litigation, nothing to go to law about: no criminal or even moral disturbance could arise, but such as reason, friendship, arbitration, or other conciliatory means, would easily compose" (W. Thompson 1824: 396).

Equality would not only assure health, good lodging, and education, but also fair views on collective happiness, bringing forth the best of every individual in benefit of the whole. Even the Malthusian danger of overpopulation would become meaningless once the causes of insecurity and inequality were eliminated altogether. As a matter of fact, the sole limitation of the Owenite communities predicted by Thompson was their outstanding capacity to provide for the well-being of its members amid a society riddled with the evils of compulsory labour. The exceptional power of cooperative unities to generate wealth, regrettably, would excite the 
taxation greed of governments to pay for the national debt and to finance the prevailing system of inequality. The only efficient corrective against the sinister intentions of authorities and the indifference of society would be, as proposed in the Inquiry, the union of workers of all descriptions around the message of cooperation and voluntary equality.

Bees labor and produce honey, and men consume it; because bees have neither knowledge nor foresight. But from these co-operating communities of human bees, knowledge and foresight cannot be withheld: they are the very fires that must kindle the mass of mankind into activity and happiness; more necessary to them than to the short-sighted calculators of individual competition in general society, whose views the necessity of existence terminates for the most part with the day or the week (W. Thompson, 1824: 441).

Here, Thompson concludes with a plea to what was indeed a common point between Bentham's and Owen's distinct approaches to social reform: the categorical necessity of making knowledge a common asset of all humankind under whatever arrangement of society.

\section{The young Mill on competition and the classical reformist agenda}

By the time of the debates at the London Cooperative Society, John Mill enjoyed a rather unique position regarding his familiarity with the canons of the classical school. During his thirteenth year, in 1819, he used to take morning walks with his father James Mill discussing the contents of Ricardo's Principles and, after that, of Smith's Wealth of Nations. After his return to England from a one-year stay in France, the young Mill had the opportunity to accompany his father to Ricardo's country house in Gatcombe on a few occasions to talk about political economy. When, in 1823, at the age of seventeen, John Mill, along with his friends Charles Austin, William Ellis, Eyton Tooke, and John Roebuck, created the Utilitarian Society, he was surely the best equipped to speak up on issues of economic nature from the classical viewpoint. In addition, James Mill had trained him hard on the development of oratorical skills, infusing in his son a rare set of qualities to occupy a position of leadership within the group (Mill, JSM I 1981 [1873]: 41-136; Packe 1954: 3-74).

Fortunately, the notes from the nineteen-year old John Mill's speeches at the London Co-operative Society have survived, showing that his main 
concern, in his first talk, was to refute the common perception that the competitive spirit, so much praised by Smith, was supposedly behind the economic evils of the time. Competition could never lower land rent or profits, observed the young Mill, for its primary effect lies in its power to level out the profitability of all undertakings. On the other hand, competition among the labourers depressed their earnings, while the same action, when performed by the employers for the hiring of labour, had the opposite effect. In case of a lessening in the competitive pressure of the first kind by a reduction in the size of families, the second one would be sufficient to guarantee a continuous advance in wages and in the living conditions of the poor.

Here, besides Malthus's views of population, John Mill is applying also Ricardo's theory of land rent, whose tendency to grow over time had been attributed to the scarcity of rich soils. By analogy, any slowdown in population growth would reduce the supply of new productive arms and, therefore, could not fail to raise the "personal rent" of labourers. That, in addition, would compress the profit rate to a level equivalent to a high wage, there being then no reason to suppress capital altogether. Land rent, for its turn, in view of the diminished need to push agriculture into barren fields, would stay at a minimum and be subject to its being taxed by the government to build roads, fund education, or even to be distributed among the working classes. In this happy situation, the British people would become as rich as their fellow American workers. In contrast to such a promising prospect, John Mill asked his audience: how could Owen's system fare better than this? Without proper population control, he answered, the Owenite communities could never reach any durable improvement. Besides that, it would not be hard to foretell the problems arising from the absence of an adequate motivation to work. Instead of going all the way for Owen's pedagogical proposals within closed communities, a national system of education could reach the same results along with the most valuable benefit of safeguarding individual autonomy (Mill, JSM XXVI 1988 [1825]: 325-326). As John Mill put down in the ninth note to his first speech:

9. Shew that the same system of education could be adopted now. E.g. infant schools, and if adopted that it would give us all that we could have by Owen's system and more: the pleasures and virtues of individual freedom of action. If then Owen's system brings men more speedily to this state, let us have it and when brought let the comm. [unity] dissolve (Mill, JSM XXVI 1988 [1825]: 326). 
Unfortunately, there are no extant accounts of Thompson's reply. From John Mill's outline of his second speech, however, it is possible to get some clues about his opponent's talk, which followed the arguments already developed in his Inquiry seen in the previous section. According to John Mill's annotations, Thompson warned his listeners against the whole assortment of evils coming from unrestricted competition, namely: the incompatibility between self-interest and benevolence; contemporary slavery; the degradation of industrial workers; the recurrent mismatches between demand and supply in many markets; wars and the government debt; the spirit of rivalry among the people; and, lastly, the adoption of machinery and the consequent increase in unemployment. On the contrary, once the Owenite communities were in place, assured Thompson, there could be competition and trade, but never rivalry or enmity, since all workers would have their subsistence assured for life.

By the time of his second speech, John Mill did not deny the social maladies evoked by Thompson, instead condemning them wholesale in the most vehement terms. He insisted, though, that none of them proceeded from the sole cause pointed out by his challenger. Men of great intellect, advised John Mill, agreed that the competitive system, complemented by democratic legislation, a general system of education, and birth control, would move society to an unparalleled level of welfare. ${ }^{11}$ The same, however, could not be said about the cooperative system, since this social arrangement would neither eliminate taxes, tithes, or land rent, nor would it make easier to have a good government, an education of quality, or a limitation in the numbers of the working population. All that the cooperative system could do was to redistribute profits and land rent, a sum not comprising a tenth part of the kingdom's annual production that would, in reality, add little to the material condition of the great body of society.

When addressing the specific evils enumerated by Thompson, John Mill counter posed that the pursuit of self-interest was not conflicting with

11 At that same time, James Mill explained, in his entry "Government" for the Encyclopedia Britannica, that the practical side of the utilitarian doctrine dwelled in the elimination of the sinister interests of the government and the aristocracy by subjecting the rulers to the will of the citizens through the extension of the franchise and the establishment of temporary parliaments (James Mill 1825a). In the entry "Education", he also made clear that men differed only by the instruction received and that, therefore, to promote true equality, the entire human race should be educated. That included the working people, for all classes suffered with the vices fostered by the ignorance and poverty afflicting the largest segment of society (James Mill 1825b). 
benevolence, since a man does not need to renounce to his enjoyments to be good. About the other issues, such as the maladjustments between demand and supply, they were intrinsic to trade, since occasional losses are always compensated by eventual windfall gains. Wars and public debt, for their turn, arise because of reckless governments, not of competition. As for machinery, the historical experience, particularly of the cotton industry, observed John Mill, had already shown that the first effects of mechanization would take the form of lesser wages, but that, after a while, the subsequent increase in production would multiply the creation of jobs. The introduction of new machines was to be feared only when, after an uncontrolled growth in population, the workers happened to be receiving very low earnings. In this case, any slight increase in unemployment could push wages below the subsistence level.

The effect of machinery may be, to lower wages for a time; the effect of machinery always is, to raise them ultimately. By increasing the produce, it always and necessarily increases the demand for labour. When the spinning jenny was introduced there can be no doubt that it threw a number of cotton spinners out of employment -but look at its ultimate effects- where one cotton spinner found employment before the invention, there is now employment for thousands (Mill, JSM XXVI 1988 [1825]: 317).

The fundamental issue for John Mill lay not in assessing whether competition and cooperation were free from dreadful consequences, since all human endeavours would be accompanied by them one way or another, but in establishing indeed a fair comparison between the harmful effects of both economic systems. He then indicated four main problems associated with cooperative communities, namely: (i) production would remain below its potential, since personal sustenance would become independent of individual effort. In this situation, each person would do what they thought strictly necessary to not be expelled from the parallelogram, and nothing else; (ii) the managers of the community, like their subordinates, would worry only about themselves, resulting thus in bad management, since whatever falls under the care of everybody, is actually no one's responsibility; (iii) the principle of cooperation, due to its corollary of universal regulation, requires a degree of control of all collective and personal issues directly opposed to individual freedom; (iv) the actual building of the parallelograms would cost a figure of around $£ 900$ million, an amount more than enough to provide the best type of education for all British inhabitants (Mill, JSM XXVI 1988 [1825]: 313-322). 
Owen's cooperative system, adverted yet the young Mill, would be feasible only if it offered real stimulus to work, assurance against bad managers, good education, and population control, in addition to the availability of large financial resources to build the parallelograms. The much-desired betterment of the working people's condition could be achieved easily, however, if the money to be spent on the few beneficiaries of the new communities were instead channelled to the reform of laws, to public education, and to advertising campaigns on the convenience of lowering birth rates, allowing thus a sustainable increase in wages. Owen's project, despite its noble intention to promote collective welfare, incurred the crucial mistake of suppressing the greatest drive of human action, that is, self-interest, which was always better to have in favour of your objective than against it. In John Mill's own words:

But the Cooperative system - look at it on its best side - I can regard only in the light in which I should consider a man who, with prodigious labour and at the peril of his own neck should employ himself in attempting to scale a twenty-foot wall, when by casting his eyes about him he would have seem a wicket gate through which he might have effected his passage without danger or difficulty (Mill, JSM XXVI 1988 [1825]: 324).

At the closing section of his second speech, John Mill elegantly bid farewell to the attending listeners, remarking that he shared with them the desire of improving humankind. He also declared his gratitude in having the opportunity to show an unbiased glimpse of the true nature of political economy, which carried within itself a flame of benevolence as genuine as the one so ably lit by Owen among his disciples (Mill, JSM XXVI 1988 [1825]: 325).

Despite our best efforts, we were unable to locate any contemporary reaction to the debate. As the years passed by, though, John Mill cultivated his very personal trait of devoting the utmost respect to divergent opinions, which he masterfully converted in a rule for his intellectual life. The progressive transformation of his views over time were mainly due to his contact with French writers and the social revolutions there, not to mention, according to his own reminiscences, the strong influence of his relationship with Harriet Taylor (Capaldi 2004: 227-241; Mill, JSM I 1981 [1873]: 246-261; Mueller 1968: 17-91, 170-259). It is undeniable, however, that in his mature years, John Mill made a conscious and concerted effort to take into consideration the aspirations of the working classes. That is evident in the third edition of his Principles of Political Economy, published 
in 1852, where he recants his previous opinion that the labourer would be disinterested in the product of his efforts under the cooperative rule. That, admitted John Mill, already happened under the wage system in industrial societies. Also, he now accepts that the community could effectively exercise the same supervising function done by the private owner of an industrial concern over the less productive labourers. But the convenience of alternative systems, he added, should be judged under equivalent conditions of general education and moderate population growth; that being the case, the scope afforded to liberty would remain the decisive factor for him (Mill, JSM II 1965a [1871]: 199-209).

The same subject is further detailed in the chapter on the future of the working classes, where John Mill, with the contribution of Harriet Taylor, sees that as the lower ranks grew progressively instructed, they become fully aware of their own interests, rejecting thus any solution alien to their condition. As long as education and autonomy made their way among wage earners, prudence would naturally diminish the growth of population behind the advance of capital, bringing about improved standards of living for all. Still, with the dissemination of the message for equality, it would become impossible to sustain a society utterly divided between employers and employees. Through the establishment of cooperative organizations among the people, everyone would be a partner in the collective endeavour and, in this way, would also be directly interested in the progress of productivity (Mill, JSM III 1965b [1871]: 758-796). ${ }^{12}$

John Mill's words in support of the cooperative experiment would not pass unnoticed, and many in the movement did not hesitate to praise his reversal in attitude over such an important subject. Right after his death in 1873, the famous co-operator George Holyoake, on behalf of the British workers, rendered an emotive tribute to the deceased philosopher:

[I]t was Mr. John Stuart Mill who, as an authority in political economy, extended to co-operation scientific recognition, and subsequently promoted, befriended, and advised all who worked for it and were at trouble to serve it. Co-operators therefore, would appear ungrateful, as well as unmindful, if some of them should not estimate the loss to them of Mr. Mill (Holyoake 1873: 3).

12 "The form of association, however, which if mankind continue a to improve, must be expected in the end to predominate, is not that which can exist between a capitalist as chief, and workpeople without a voice in the management, but the association of the labourers themselves on terms of equality, collectively owning the capital with which they carry on their operations, and working under managers elected and removable by themselves" (Mill, JSM III 1965b [1871]: 775). 
Last of all, a brief comment on John Mill's reflections in his Chapters on Socialism (1879), published posthumously, is in order at this point. Although he had made a definite about-turn on the issue of cooperation, he never wavered on the imperative of liberty as the key condition for a progressive society, a belief he carried unchanged in his heart from his early youth, as seen in his first speech at the London Co-operative Society. Two main reasons are brought up in the Chapters in opposition to the then proposed centralized communist control of society. First, once the possibility of improving one's condition through personal exertion got suppressed, the material wealth of society would be fatally hurt. Second, since individual liberty could be suppressed beyond remedy, that prospect looked wholly unacceptable to John Mill, since any real evolution in social life, according to his long-held belief, would always start by some type of deviant behaviour (Mill, JSM XVIII 1967 [1879]: 704-711). ${ }^{13}$ Albeit John Mill made substantial concessions to cooperative ideas in his mature life, it never reached the point of renegading his deep commitment to individual freedom (for more on that, see Capaldi 2004: 350-357; Clayes 1987b).

\section{Concluding remarks}

The constitution of debating societies in late eighteenth century Britain marked an essential step in its social history by crystalizing the fact that the common people, although deprived of the right to vote, cherished indeed democratic arrangements in which opposing ideas and freedom of speech were paramount. Despite the aggressive persecution of these societies and the radical press, that tradition emerged even stronger in the years after the Napoleonic Wars, assuming a more practical quest for political reform and giving birth to all kinds of cooperative associations with the intent of sharing not only economic benefits, but also a new form of knowledge. It was inevitable, therefore, that at some point the two main reformist strands of the period within the British society, inspired respectively by Bentham and Owen, would come to a showdown, as did happen 13 As he, along with Harriet Taylor, had remarked in their famous book On Liberty (1859): "[W] hen the opinions of masses of merely average men are everywhere become or becoming the dominant power, the counterpoise and corrective to that tendency would be, the more and more pronounced individuality of those who stand on the higher eminences of thought" (Mill, JSM XVIII 1977 [1859]: 269). 
after all at the London Co-operative Society in 1825.

From what we have seen, William Thompson based his concept of exploitation in Ricardo's labour theory of value, even though Smith's ideas respecting the advantages of a system of natural liberty were gladly adopted in his critique of capitalism. Bentham, however, had a heavier influence on Thompson's analytical structure, which centred on the question of how to solve the perennial dilemma between security, on the one hand, and equality, on the other. His solution, however, guided him toward Owen's critical approach of contemporary society, searching for a way out of exploitation and poverty through the spread of autonomous communities secluded from the dominant capitalistic order.

John Mill, for his part, reached quite opposite conclusions starting from almost the same personal references. He took from Smith the general proposition that the system of competition was the best way to make self-interest a useful force for society. Ricardo, besides that, gave him the faith in the power of markets to assure the general accordance between supply and demand, as well as the recommendation of taxing land rent in favour of all. Malthus, of course, also played a large role in John Mill's early thoughts through his warnings on the dangerous consequences of overpopulation. Lastly, Bentham, along with the fatherly teachings of James Mill, had already convinced the young philosopher about the necessity of adopting a reformist agenda, giving prominence to democratic laws, public education and, above all, personal liberty.

Finally, even though Joseph Schumpeter (1963: 473-479) and Karl Marx (1968: chap. XX) have pointed out that by the 1820s British political economy had started its long-term decline, the match-up between William Thompson and John Mill seems to indicate that such was hardly the case. Instead, both intellectuals, notwithstanding their widely distinct objectives, sought to underpin their well-articulated reasonings with a rich assortment of theoretical elements provided not only by well-known classical economists but also by prestigious contemporary social reformers.

\section{References}

Andrew, D.T. 1996. "Popular culture and public debate: London 1780. The Historical Journal, 39(2), 405-423. 
Beer, M. 1923. History of British Socialism. London: London and Norwich Press.

Bentham, J. 1938 [1802]. Principles of the Civil Code. In J. Bowring (ed.). The Works of Jeremy Bentham. Vol. I. New York: Russel \& Russel, 297-364.

Bentham, J. 1938 [1789]. An Introduction to the Principles of Moral and Legislation. In J. Bowring (ed.). The Works of Jeremy Bentham. Vol. I. New York: Russel \& Russel, 1-154.

Bentham, J. 1843 [1823]. Leading Principles of a Constitutional Code, for Any State. In J. Bowring (ed.). The Works of Jeremy Bentham, vol. II. New York: Russel \& Russel, 267-274.

Booth, J.A. 1869. Robert Owen. The Founder of Socialism in England. London: Trubner.

Capaldi, J. 2004. John Stuart Mill. A Biography. Cambridge, UK: Cambridge University Press.

Checkland, S.G. 1949. "The propagation of Ricardian economics in England". Economica, New Series, 16(61), 40-52.

Claeys, G.1987a. Machinery, Money and the Millennium. From Moral Economy to Socialism 1815-1860. Princeton: Princeton University Press.

Claeys, G. 1987b. "Justice, independence, and industrial democracy: The development of John Stuart Mill's views on socialism". The Journal of Politics, 49(1), 122-147.

Cole, G.D.H. 1953. Socialist Thought. The Forerunners 1789-1850. London: Macmillan.

Crimmins, J.E. 1994. "Bentham's political radicalism re-examined". Journal of the History of Ideas, 55(2), 259-281.

Gray, A. 1946. The Socialist Tradition. Moses to Lenin. London: Longmans, Green.

Halévy, E. 1949. The Liberal Awakening 1815-1830. London: Ernest Benn.

Halévy, E. 1969. The Growth of Philosophic Radicalism. London: Faber and Faber.

Holyoake, G. 1873. John Stuart Mill, as Some of the Working Classes Knew Him. London: Trubner.

Hyndman, H.M. 1902. Commercial Crises of the Nineteenth Century. London: Swan Sonnenschein.

Kaufmann, M. 1879. Utopias or Schemes for Social Improvement. From Thomas More to Karl Marx. London: C. Kegan Paul.

Lowenthal, E. 1911. The Ricardian Socialists. New York: Columbia University.

Marx, K. 1968. Theories of Surplus Value. Moscow: Progress Publishers.

McCalman, I. 1987. "Ultra-Radicalism and Convivial Debating-Clubs in London, 1795-1838". The English Historical Review, 102(403), 309-333.

Mill, J. 1825a. Government. Reprinted from the Supplement to the Encyclopaedia Britannica. London: J. Innes.

Mill, J. 1825b. Education. Reprinted from the Supplement to the Encyclopaedia Britannica. London: J. Innes.

Mill, J.S. 1988 [1825]. Notes on Cooperation 10-13, in J.M. Robson (ed.) Collected Works of John Stuart Mill. Vol. XXVI, Journals and Debating Speeches, Toronto: University of Toronto Press, 308-326.

Mill, J.S. 1965a [1871]. Principles of Political Economy, Part I, $7^{\text {th }}$ ed., in J.M. Robson and J. Stillinger (eds.) Collected Works of John Stuart Mill. Vol. II, Toronto: University of Toronto Press. 
Mill, J.S. 1965b [1871]. Principles of Political Economy, Part II, $7^{\text {th }}$ ed., in J.M. Robson and J. Stillinger (eds.) Collected Works of John Stuart Mill. Vol. III, Toronto: University of Toronto Press.

Mill, J.S. 1977 [1859]. On Liberty, in J.M. Robson and A. Brady (eds.) Collected Works of John Stuart Mill. Vol. XVIII, Essays on Politics and Society, Toronto: University of Toronto Press, 213-310.

Mill, J.S. 1981 [1873]. Autobiography, in J.M. Robson and J. Stillinger (eds.) Collected Works of John Stuart Mill. Vol. I, Autobiography and Literary Essays, Toronto: University of Toronto Press, 3-290.

Mill, J.S. 1967 [1879]. Chapters on Socialism, in J.M. Robson (ed.) Collected Works of John Stuart Mill. Vol. V, Essays on Economics and Society, Toronto: University of Toronto Press, 703-53.

Morton, A. L. 1978. The Life and Ideas of Robert Owen. New York: International Publishers.

Mueller, I.W. 1968. John Stuart Mill and French Thought. New York: Books for Libraries.

O'Brien, D.P. 2004. The Classical Economists Revisited. Princeton: Princeton University Press.

Owen, R. 1817. Report to the Committee of the House of Commons on the Poor Laws. In R. Owen. The Life of Robert Owen. A Supplementary Appendix to the First Volume. London: Effingham Wilson, 53-64.

Owen, R. 1920 [1857]. The Life of Robert Owen by Himself. London: G. Bell and Sons.

Packe, M. S. J. 1954. The Life of John Stuart Mill. New York: Macmillan.

Pankhurst, R. 1991. William Thompson (1755-1833). Pioneer Socialist. London: Pluto Press.

Parolin, C. 2010. Radical Spaces. Venues of Popular Politics in London, 1790-c.1845. Canberra: Australian National University Press.

Potter, B. 1904. The Cooperative Movement in Great Britain. London: Swan Sonnenschein.

Schumpeter, J.A. 1963. History of Economic Analysis. London: George Allen \& Unwin.

Shawl, W.F. 1954. The Repeal of the Combination Acts 1824-1824. University of Montana, Theses, Dissertations, Professional Papers. Paper 8628

Stephen, L. 1912. The Utilitarians. Volume I. Jeremy Bentham. London: Duckworth.

Thale, M. 1989. "London Debating Societies in the 1790s". The Historical Journal, 32(1), 37-56.

Thale, M. 1997. "The Robin Hood Society: Debating in eighteenth century London". The London Journal, 22(1), 33-50.

Thompson, N.W. 2002. The People's Science. The Popular Political Economy of Exploitation and Crisis 1816-1834. Cambridge, UK: Cambridge University Press.

Thompson, E.P. 1963. The Making of the English Working Class. New York: Vintage Books.

Thompson, W. 1824. An Inquiry into the Principles of the Distribution of Wealth Most Conducive to Human Happiness. London: Longman et al.

Trevelyan, G.M. 1930. British History in the Nineteenth Century (1782-1901). London: Longmans, Green.

Viner, J. 1949. "Bentham and J.S. Mill: The utilitarian background". The American Economic Review, 39(2), 360-382. 
Weinstein, B. 2002. "Popular constitutionalism and the London Corresponding Society". Albion: A Quarterly Journal Concerned with British Studies, 34(1), 37-57.

\author{
About the authors \\ Carlos Leonardo Kulnig Cinelli - carloscinelli@hotmail.com \\ Universidade de Brasília - UNB. \\ RogérioArthmar-rogerio.arthmar@ufes.br \\ Universidade Federal do Espírito Santo - UFES. \\ Acknowledgements: The authors thank the valuable suggestions by Nova Economia's two anonymous referees and \\ gratefully acknowledge the financial support from CNPq, grant number 305168/2015-0.
}

\title{
About the article
}

Submission received on August 06, 2016. Approved for publication on March 09, 2018. 